\author{
JERZY SOJKA \\ Christian Theological Academy in Warsaw \\ (D) https://orcid.org/0000-0003-1154-5658
}

\title{
Lutheran service to the migrants. Global and Polish experiences
}

\begin{abstract}
The article presents Lutheran engagement for migrants, using the examples of activities undertaken by the Evangelical Church of the Augsburg Confession in Poland, as well as by the Lutheran World Federation, which is the biggest global organisation of Lutheran Churches all over the world. In case of the Evangelical Church of the Augsburg Confession the text provides an overview of the initiatives undertaken since 2015 in service to the migrants on the parish and Church levels, as well as in cooperation with ecumenical partners (including the activities within the Polish Ecumenical Council and in cooperation with the Catholic Church). In case of the Lutheran World Federation, the first step was to present the theological justification for the Federation's engagement in the work for migrants, and the next one - to outline the characteristics of the work of the Department for World Service (Federation's humanitarian agency) in 2018.
\end{abstract}

Keyword: Lutheran World Federation, migrants, mission of the Church, Evangelical Church of Augsburg Confession in Poland

Service to migrants belongs to the fundamental elements of Christian service to one's neighbour or, more broadly, service to the surrounding world. This article collects and presents experience in this field gathered by the Lutheran Churches in Poland and in the world, that is, examples of concrete actions taken by Lutherans to respond to the needs of migrants. They will be presented in the following steps. First of all, initiatives conducted at the Evangelical Church of the Augsburg Confession in Poland on the parish level. Secondly, the involvement on the whole Church's level, and thirdly - on the ecumenical level. The global perspective will be represented by the experience of the Lutheran World Federation (LWF). 
The fourth part of this text will present the LWF's reflection on commitment to migrants, which also gives the insight into the theological rationale of this commitment, while the fifth and last part will outline the practical activities of the LWF conducted by its Department for World Service in 2018.

\section{Polish experiences - parish level}

We begin the presentation of Polish experience in the service to the migrants with the initiatives of individual parishes of the Evangelical Church of the Augsburg Confession in Poland because it is on the level of diaconal organizations in dioceses and parishes that practical actions are taken for the needy. ${ }^{1}$ Hence, below are two parish initiatives taken by the Diaconia of the Evangelical-Augsburg Parish of Jesus the Good Shepherd in Koszalin, and diaconal activities undertaken as part of the activities of St. Trinity Evangelical-Lutheran Church in Warsaw.

The first of the initiatives is an answer to the needs of the migrants who are looking for a possibility to earn a living in Poland. In the middle of last year in Koszalin the Diaconia ${ }^{2}$ working at the Parish of Jesus the Good Shepherd ${ }^{3}$ started the project "Together - Infopoint for migrants". Its aim is to provide support to the people who came to Koszalin from abroad, looking for work. They are mainly from Ukraine, but also from Belarus and Russia. In the previous months, an increase of the number of migrants from the Philippines could also be observed. The Infopoint is a place where migrants can find support in their search for work, a place to live, dealing with the official matters etc. It is a unique place in Koszalin. An important element of Infopoint's operations is the organization of the Polish language courses for foreigners. They are free, students only bear the cost of textbooks. So far, there have been three such courses, each of which attended by about 20 people. Further ones were planned (recruitment for a course starting in May 2019), and from autumn 2019 integration activities for children combined with learning the Polish language were to be launched. Knowledge of the language, as indicated by the project coordinator Izabela Główka-Sokołowska, is a key competence

${ }^{1}$ Cf. Jak działamy. http://www.diakonia.org.pl/o-diakonii/jak-dzialamy/ [access: 5.08.2019].

${ }^{2}$ Cf. Diakonia Koszalin. http://www.diakonia-koszalin.pl/ [access: 5.08.2019].

3 Cf. Parafia Ewangelicko-Augsburska Jezusa Dobrego Pasterza w Koszalinie, http:// koszalin.luteranie.pl/ [access: 5.08.2019]. 
that enables migrants to better function in the society into which they have come and in which they want to live. It also allows them to know and exercise their rights, as well as to fulfil their obligations. According to Główka-Sokołowska, the strength of the project is that Diaconia Koszalin is not associated in any way with migrants from the East. This breaking of the stereotype is conducive to seeking help at Infopoint by migrants because they treat the point as an aid organization free from their native religious or political context. An integral part of the project are initiatives promoting Infopoint's activities, such as a website (also available in Ukrainian) or a Facebook fan page. The project is financed by the Diakonisches Werk Mecklenburg-Vorpommern e. V. [Diaconia of Meklemburg-Vorpommern] ${ }^{4}$ and Brot für die Welt [Bread for the World $^{5}$ - developmental work organization of the Evangelical Church of Germany. ${ }^{6}$

The other example of activities on the parish level are the activities of the St. Trinity Evangelical-Lutheran Church in Warsaw, ${ }^{7}$ which started as a response to the migrant crisis in Europe in 2015. In response to the news of the growing refugee crisis, the parish council decided to involve the parish in practical assistance. Contacts with organizations helping refugees in Croatia were established and in response to their needs, a material collection was organized in November 2015 (clothes, blankets, basic hygiene products). The collection was also attended by the congregations of the Reformed Evangelical Church in Poland, the Old Catholic Mariavite Church in Poland, and the informal Charity Group Freta, as well as the Polish-French La Fontaine School and Kindergarten, Primary School No. 46, American School, the Place of Women Foundation and the Jewish Community Centre in Warsaw. The collected gifts were given to the Croatian Red Cross in two transports in December 2015 and in February 2016. The parish did not limit itself to collecting material assistance. In cooperation with the lawyers, in November 2015 a document Help for the refugees. Manual for the St. Trinity Evangelical-Lutheran Church was pre-

${ }^{4}$ Cf. Diakonie in Mecklenburg-Vorpommern, http://www.diakonie-mv.de/ [access: 4.04. 2019].

${ }^{5}$ Cf. Brot für die Welt, https://www.brot-fuer-die-welt.de/ [access: 3.04.2019].

${ }^{6}$ Description of this initiative was based on its website: Razem-Infopunkt dla migrantów. https://www.razeminfopunkt.pl/ [access: 5.08.2019]; its Facebook page: Razem - Infopunkt dla migrantów / Разом - пункт інформації для мігрантів, https://www. facebook.com/razeminfopunkt/ [access: 4.04. 2019]; and an interview with the Polish coordinator of the project, Izabela Główka-Sokołowska conducted on April 23, 2019 (note in author's archives).

7 Cf. Parafia Ewangelicko-Augsburska św. Trójcy w Warszawie, http://www.trojca. waw.pl/ [access: 5.08.2019]. 
pared. ${ }^{8}$ This document contains basic information about legal procedures regarding the protection of foreigners in Poland and European Union, social and medical assistance addressed to them, analysed the possibilities of parish involvement and presents its possible forms, as well as provides in its appendix the contact information to state organizations and agencies that deal with foreigners' issues. ${ }^{9}$

Activities from the years 2015/2016 were continued at the turn of 2018/2019, when at St. Trinity Evangelical-Lutheran Church the project "Refugee-Brother-Human" [Polish Uchodźca. Brat. Człowiek] was launched. As part of it so far, an ecumenical service for refugees has been held, and cooperation has been undertaken with the Małgorzata JasiczekGebert Foundation Refugee.pl, ${ }^{10}$ which presented two photography exhibitions in the church: O krok od raju... [One step away from paradise...], documenting the last migration crisis in Poland and on the European borders, and Raz, dwa, trzy, uchodźca będziesz ty... [One, two, three... You'll be a refugee] - a collection of photographs made by children - refugees in the centres for foreigners in Poland. ${ }^{11}$ As part of the project, there was also a children's charity concert for refugees. The proceedings from it (PLN 5,095.41) were transferred to the Refugee.pl foundation. The activities were subsequently continued at the conference "Refugee. Brother. Human" organized by St. Trinity Evangelical-Lutheran Church in Warsaw in cooperation with Christian Theological Academy in Warsaw ${ }^{12}$ and the Refugee.pl foundation. During the conference, the students of the Christian Theological Academy in Warsaw and the guests could familiarize

${ }^{8}$ M. Mączka-Pacholak, Z. Morawska, M. Radziejowska: Pomoc dla uchodźców. Vademecum dla Parafii Ewangelicko-Augsburskiej. 19 listopada 2015. Unpublished materials in the author's archive.

${ }^{9}$ Description of this initiative was based on media reports: Pomoc dla uchodźców, http://www.trojca.waw.pl/44-serwis-informacyjny/w-parafii/1087-pomocdla-uchodzcow.html [access: 26.02.2019]; Pomoc dla uchodźców przekazana, http:// www.trojca.waw.pl/44-serwis-informacyjny/w-parafii/1104-pomoc-dla-uchodzcowprzekazana.html [access: 26.02.2019]; Drugi transport pomocy humanitarnej, http:// www.trojc a.waw.pl/44-serwis-informacyjny/w-parafii/1132-drugi-transport-pomocyhumanitarnej.html [access: 26.02.2019]; Pomoc dla uchodźców przekazana Zakończono akcję $w$ Parafii św. Trójcy $w$ Warszawie, https://www.luteranie.pl/nowosci/pomoc_dla_ uchodzcow_przekazana,3510.html [access: 26.02.2019]; and materials made available by the project coordinator at the St. Trinity Evangelical-Lutheran Church in Warsaw Justyna Stanisławska (correspondence in the author's archive).

${ }^{10}$ Cf. Fundacja Refugee.pl im. Małgorzaty Jasiczek-Gebert, http://refugee.pl/ [access: 5.08.2019].

${ }^{11}$ Cf. Migrating exhibitions, http://refugee.pl/en/information/migrating-exhibitions/ [access: 5.08.2019].

${ }^{12}$ Cf. Chrześcijańska Akademia Teologiczna w Warszawie, www.chat.edu.pl [access: 5.08.2019]. 
themselves with the biblical perspective on migrations, the projects aimed at helping migrants, and exhibitions which had been presented earlier in the St. Trinity Church in Warsaw. ${ }^{13}$

\section{Polish experience - Church level}

The involvement of the Evangelical Church of the Augsburg Confession in Poland in the refugee cause in recent years is not only limited to the initiatives at parish level. ${ }^{14}$ As an important initiative in this regard, the pastoral letter of Jerzy Samiec, the Bishop of the Church, dated 9th of September 2015 should be mentioned. The letter included a call to openness to migrants, also in the face of media and political tensions in this context, as well as the fears that accompany people in the face of the meeting with others. In addition, the Bishop of the Church pointed to the practical role that the church can play in the face of the migration crisis. He also reminded unequivocally that serving one's neighbour, stranger, and passer-by in need is a Christian imperative. This is how he ended his letter: "Let us be a Church serving God through the love that we express

${ }^{13}$ Description of this initiative was based on media reports: "Nabożeństwo ekumeniczne oraz wystawa fotografii," http://www.trojca.waw.pl/44-serwisinformacyjny/w-parafii/1461-nabozenstwo-ekumeniczne-oraz-wystawa-fotografii.html [access: 26.02.2019]; “Wystawa fotografii o życiu uchodźców 7-27 stycznia,” http:// www.trojca.waw.pl/44-serwis-informacyjny/w-parafii/1465-wystawa-fotografii-o-zyciuuchodzcow-7-27-stycznia.html [access: 26.02.2019]; “Otwarcie wystawy w ramach projektu Uchodźca. Brat. Człowiek,” https://www.trojca.waw.pl/44-serwis-informacyjny/ w-parafii/1463-otwarcie-wystawy-w-ramach-projektu-uchodzca-brat-czlowiek.html [access: 26.02.2019]; “Dziecięcy Koncert Dobroczynny już w niedzielę 20.01.,” http://www. trojca.waw.pl/44-serwis-informacyjny/w-parafii/1466-dzieciecy-koncert-dobroczynnyjuz-w-niedziele-20-01.html [access: 26.02.2019]; "Photo Exhibition at The Holy Trinity Lutheran Church in Warsaw," http://refugee.pl/en/information/art-exhibition/ [access: 26.02.2019]; “Uchodźca. Brat. Człowiek. Konferencja i wystawa," http://chat.edu. pl/app/uploads/2019/02/uchodzca-brat-czlowiek-3.pdf [access: 26.02.2019]; "Relacja z konferencji Uchodźca. Brat. Człowiek - Chrześcijańska Akademia Teologiczna w Warszawie," http://chat.edu.pl/aktualnosci/relacja-z-konferencji-uchodzca-brat-czlowi ek/?fbclid=IwAR0zWc5RvmoDKdp-OpakApZI8UZHHjkCUD9gyHDkNhuXICZ7hIG5M 8XRnf0 [access: 26.02.2019]; and materials made available by the project coordinator at the Evangelical St Trinity Parish in Warsawa Justyna Stanisławska (correspondence in the author's archive).

${ }^{14}$ I want to thank the spokeswoman of the Evangelical Church of the Augsburg Confession in Poland, Agnieszka Godfrejów-Tarnogórska, for her help in collecting materials on the whole-Church initiatives discussed hereinafter. 
through helping the poor. Let us love the refugees, because in them Christ comes to us (Matth. 25,31-46)."15

Specific actions followed this call. In September 2015, Diaconia Poland announced a fundraiser to help refugees. In the accompanying letter to the Bishop of the Church, Rev. Jerzy Samiec, together with the President of Diaconia Poland, a retired bishop of the Diocese of Wrocław, Rev. Ryszard Bogusz wrote: "Let us be those who welcome refugees with an open heart and generosity. Our prayers and concrete, even the smallest financial support, can help them survive this very difficult time and give hope for further life." ${ }^{16}$ Another initiative to raise funds for refugee assistance was a Churchwide fundraiser during Sunday services on 8th of November 2015 across the Evangelical Church of the Augsburg Confession in Poland, in order to help refugees in camps in the Middle East: Jordan, Iraq, Lebanon, and Turkey. The collected funds (PLN 66,409.51) were donated to work with refugees of the Lutheran World Federation. ${ }^{17}$ As a part of this cooperation, in 2016 the Bishop of the Church, Rev. Jerzy Samiec visited the refugee camp run by the World Lutheran Federation in Zataria, Jordan. ${ }^{18}$

As a part of cooperation with its foreign partners, the Evangelical Church of the Augsburg Confession in Poland also organized study visits for representatives of the Consistory and Diaconia Poland with German partners in 2015 and 2016, aimed at getting acquainted with the work for migrants conducted by German deacon centres. ${ }^{19}$ They also presented the experience gathered in Poland on the ecumenical consultation organized in Munich jointly by the World Council of Churches and Evangelical Lutheran Church in Bavaria, at the inter-Church consultation forum organized by the Evangelical Church in the Rhineland (EKiR), as well as at the synod of this Church. ${ }^{20}$ As a part of interna-

15 Otwórzmy serca dla uchodźców. List pasterski Biskupa Kościoła, https://www. luteranie.pl/nowosci/otworzmy_serca_dla_uchodzcow,3175.html [access: 4.04.2019].

${ }^{16} \mathrm{Na}$ pomoc uchodźcom. Apel Diakonii Polskiej, https://www.luteranie.pl/nowosci/ na_pomoc_uchodzcom,3185.html [access: 4.03.2019].

17 "Nie możemy stać obojętni. Zebrano ofiarę na pomoc uchodźcom," https://www. luteranie.pl/nowosci/nie_mozemy_stac_obojetni,3419.html [access: 4.03.2019]; "Wsparcie od polskich luteran. Przekazano środki finansowe dla uchodźców," https://www. luteranie.pl/nowosci/wsparcie_od_polskich_luteran,3957.html [access: 4.03.2019].

18 "W obozie dla uchodźców w Jordanii," https://www.luteranie.pl/nowosci/w_ obozie_dla_uchodzcow_w_jordanii,4316.html [access: 4.04.2019].

19 "Dostrzec miłość. Wizyta studyjna pracowników Biura Konsystorza i Diakonii," https://www.luteranie.pl/nowosci/dostrzec_milosc,3164.html [access: 4.03.2019]; “Poznać pracę z uchodźcami," https://www.luteranie.pl/nowosci/poznac_prace_z_ uchodzcami,3655.html [access: 4.03.2019].

20 "Konsultacje dotyczące uchodźców. Ekumeniczne spotkanie w Monachium," https://www.luteranie.pl/nowosci/konsultacje_dotyczace_uchodzcow,3384.html [access: 4.03.2019]; "Sami byliście przychodniami. Konsultacje międzykościelne i Synod EKiR," 
tional cooperation, Evangelical Church of the Augsburg Confession in Poland joined the ChristmasStory.World ${ }^{21}$ campaign in 2015, conducted by the Evangelical Church in the Rhineland (EKiR), within which a film (also in a Polish-language version ${ }^{22}$ ) presenting the connections between Christmas story and the issues of migration and refugees was screened. ${ }^{23}$ The church also joined the international \#BellsForAleppo action. Bishop of the Church, Jerzy Samiec, encouraging the faithful to join it, wrote in a letter:

The situation in Syria is becoming increasingly difficult, and the most intense fights are taking place in Aleppo. [...] On a daily basis, we receive very little news on this subject, they are lost among other media reports. At the same time, all this is taking place, even if we do not notice it. I saw the tragedy of Syrians with my own eyes while in a Jordanian refugee camp. The war took their homes and forced them to flee. Although they have temporarily found shelter, they are still fighting for their dignity and need hope for a better future. Time for bells to sound also in churches in Poland. Time for us to express our sadness, but also solidarity and support with our prayers. ${ }^{24}$

In 2015, the subject of refugees and migration became the subject of one of the sessions of the Synod of the Church. The impulse to discuss it was not only the situation in Europe at the time, but also the biblical slogan of 2015: “Accept one another, then, just as Christ accepted you, in order to bring praise to God" (Rom. 15.6). The synodals also fundraised (the proceedings amounted to PLN 3,100), which was donated to refugees help run by the Evangelical Lutheran Church in Hungary. Also in 2018, the issue of refugees was of interest to the highest church bodies. The Synod Council and Consistory of the Church issued a joint statement on World Refugee Day on 20th of June 20. We read in it:

"On 20th of June, the international community celebrates World Refugee Day. This holiday was established by the United Nations Gen-

https://www.luteranie.pl/nowosci/sami_byliscie_przychodniami,3592.html [access: 4.03.2019].

${ }^{21}$ Cf. ChristMasstory.World, http://christmasstory.world/ [access: 5.08.2019].

22 Cf. Christmas Story (Polski), http://christmasstory.world/polish/christmas-storypolski-117/ [access: 5.08. 2019]. The film is also available in English, Arabic, French, Spanish, German, and Portuguese.

23 "Historia Bożego Narodzenia. Świat wokół nas — projekt filmowy Kościoła Nadrenii," https://www.luteranie.pl/nowosci/historia_bozego_narodzenia,3546.html [access: 4.04.2019].

${ }^{24}$ Dzwony pokoju dla Aleppo. Apel Biskup Kościoła, https://www.luteranie.pl/ nowosci/dzwony_pokoju_dla_aleppo,4354.html [access: 4.03.2019]. 
eral Assembly on 4th of December 2000, to commemorate the courage and strength of refugees around the world. The Consistory and Synod Council of the Evangelical Church of Augsburg Confession in Poland with understanding, awareness of the complexity of the issues and guided by a sense of responsibility and love for human person in all walks of their lives, joins the actions carried out that day and encourages Poles to remember, pray, help materially, and actively cooperate to understand and solve the problems of people fleeing persecution, war and violence." 25

In the following part the signatories of the letter: Bishop of the Church and the President of the Consistory, Rev. Jerzy Samiec and the President of the Synod, Rev. Adam Malina, PhD list various actions and encourage to take part in them. Among them was the initiative to display the refugee flag at the headquarters of the Church authorities in Warsaw prepared by the artist of Syrian origin Yara Said, encouragement to participate in the picnic organized by the POLIN Museum of the History of Polish Jews and the Salvation Foundation in the "Leśmian's Meadow" on the occasion of World Refugee Day. It was also pointed out, that the Church offers to organize parish workshops on the topic of refugees, in cooperation with Ocalenie Foundation. ${ }^{26}$ It is worth mentioning here that similar workshops, during which participants had the opportunity to empathize with the emotional situation of migrants during the situational game, were in 2015 and 2016 in the programme of the Pastoral Institute of the Evangelical Church of the Augsburg Confession in Poland, and therefore become part of the Church's education for its future (students of Evangelical theology at the Christian Theological Academy in Warsaw) and young staff (apprentices preparing for ordination and vicars). ${ }^{27}$ The statement also indicated that this topic would appear in the programme of the largest evangelization initiative organized by the Church, namely, the Evangelization Week in Dzięgielów, which takes place during the seminars ${ }^{28}$ dedicated to the work of the "Nadzieja dla Narodów" (Hope for the Nations) foundation, or presentation of the "Gościnny Kościół" (Hos-

${ }^{25}$ Światowy Dzień Uchodźcy. Oświadczenie Konsystorza i Rady Synodalnej, https:// www.luteranie.pl/nowosci/swiatowy_dzien_uchodzcy,5562.html [access: 4.03.2019].

${ }^{26}$ Cf. "Przekraczając granice - zrozumieć uchodźców. Projekt warsztatów dotyczących sytuacji uchodźców w Polsce," https://www.luteranie.pl/nowosci/ przekraczajac_granice_zrozumiec_uchodzcow,5446.html [access: 4.03.2019].

27 Sesja Instytutu Pastoralnego 15-20 lutego 2016 r. Wrocław, http://pastoralny. luteranie.pl/tematyka-sesji/194-2016-wroclaw [access: 4.03.2019]; Instytut Pastoralny Wisła Jawornik, 29-31 maja 2015. http://pastoralny.luteranie.pl/dotychczas/187-2015 [access: 4.03.2019].

${ }^{28}$ Program TE Dzięgielów 2018, https://cme.org.pl/content/uploads/2018/04/ Program_TED_2018_.pdf [access: 4.03.2019]. 
pitable Church) programme of the Polish Ecumenical Council, which will be presented in more detail hereinafter. ${ }^{29}$

\section{Polish experience - ecumenical level}

Evangelical Church of the Augsburg Confession in Poland is also active in the field of helping migrants to help her ecumenical activity. This takes place mainly as a part of the work within the Polish Ecumenical Council, being one of its seven member Churches. ${ }^{30}$ Within the ecumenical activities in or with the Polish Ecumenical Council it is worth mentioning two significant initiatives.

The first is the Message from the Churches in Poland concerning Refugees of 30th of June 2016 prepared jointly by the member Churches of the Polish Ecumenical Council and the Roman Catholic Church. We may read in it, among others:

The nations of Europe and the Churches are facing the enormous challenge of the migrant crisis. About three million people from countries of Africa and Asia have crossed the border of the European Union. Some of them are fleeing because of war and religious persecution, others in a search for a better life. [...] Poland too has been facing this challenge. The obligations of Christians concerning this stem from Divine Revelation and the Tradition of the Churches. [...] The task of the Churches is to prepare people's hearts to provide assistance, by specific acts of mercy, to those who suffer - those escaping from war, persecution and death. Such an attitude by Christians to others has been their particular feature ever since the beginnings of the Church. ${ }^{31}$

The second of the initiatives worth mentioning is the project "Ecumenical Consultation Point on Migration - Hospitable Church," which has been running since 1st of November 2017. As a part of it, annual nationwide and regional consultations in agreement with the branches of the Polish Ecumenical Council and training for multipliers, that is, people who, after proper preparation (a series of workshops on interpersonal and

${ }_{29}$ Światowy Dzień Uchodźcy. Oświadczenie Konsystorza i Rady Synodalnej, https:// www.luteranie.pl/nowosci/swiatowy_dzien_uchodzcy,5562.html [access: 4.03.2019].

30 "Who we are," https://ekumenia.pl/kim-jestesmy/?lang=en [access: 5.08.2019].

${ }^{31}$ Message from the Churches in Poland concerning Refugees, https://ekumenia.pl/ content/uploads/2016/06/przeslanie-Kosciolow-w-sprawie-uchodzcow-EN.pdf [access: 4.03.2019]. 
communication skills as well as intercultural and interreligious competences) will be able to transfer the know-how when it comes to helping refugees in their churches. As part of the project, information meetings are held in churches and a consultation point operates at the headquarters of the Polish Ecumenical Council in Warsaw. ${ }^{32}$

As a supplement to the initiatives above, it is also worth noting the ecumenical services held in the intention of refugees in January 2018 as part of the St. Trinity Evangelical-Lutheran Church in Warsaw within the project "Refugee. Brother. Human". In addition, already in 2015 there was a series of ecumenical services co-organized by the Polish Ecumenical Council in Cracow, Warsaw, Poznań, Kielce, Szczecin, Wrocław, Ełk, Opole, Gdańsk, and Koszalin. ${ }^{33}$ And thanks to the President of the Polish Ecumenical Council - Bishop of the Lutheran Church Rev. Jerzy Samiec, that topic was also present during the Week of Prayer for Christian Unity in $2016 .^{34}$

\section{Global experiences - the place of service to the migrants in the reflection of the Lutheran World Federation}

The basic Lutheran organization that takes upon itself the work with migrants is the Lutheran World Federation - A Communion of Churches, which is the largest international organization of Lutheran Churches. Today, it is a community of Churches gathering 148 member Churches from 99 countries of the world, which represent over 75.5 million Christians from all over the world. ${ }^{35}$

Serving migrants is one of the areas of the organization's work since its beginning, that is, since the founding General Assembly in Lund, Sweden, in 1947. The practical need to coordinate assistance to migrants after the Second World War provided by Lutheran Churches in the United States and Scandinavia was one of the main reasons of strengthening the

32 Based on the project's website: Projekt „Ekumeniczny punkt konsultacyjny ds. migracji — Gościnny Kościół,” https://ekumenia.pl/goscinny-kosciol/ [access: 4.03.2019].

33 Siła modlitwy $w$ Krakowie, https://www.luteranie.pl/nowosci/sila_modlitwy_w_ krakowie,3233.html [access: 4 .03.2019].

${ }^{34}$ Modlitwa i wzajemna miłość. Biskup Kościoła podczas Tygodnia Modlitw o Jedność Chrześcijan, https://www.luteranie.pl/nowosci/modlitwa_i_wzajemna_milosc,3622.html [access: 4.03.2019].

35 Cf. "About the LWF," https://www.lutheranworld.org/content/about-lwf [access: 5.08.2019]. 
cooperation between Lutheran Churches that led to the founding of the Lutheran World Federation in 1947. ${ }^{36}$ In the Polish context it is worth noting that the Evangelical Church of the Augsburg Confession in Poland was one of the founding members of that organization. ${ }^{37}$ Adopted at the General Assembly at the Lund, the Constitution also included assistance to Lutheran groups in need of material and spiritual support. This decision, taking into account the situation in post-war Europe, has become a permanent element of the LWF's operations. All subsequent versions of the LWF Statute included the support of diaconal work for the needy among the organization's goals. In the current version of the Constitution, this objective is defined as follows:

"The Lutheran World Federation [...] furthers worldwide among the member churches diaconic action, alleviation of human need, promotion of peace and human rights, social and economic justice, care for God's creation and sharing of resources." 38

The importance that serving refugees has for the LWF identity was confirmed in the study process that took place in the years 2014-2016 as a preparation for the jubilee year 2017 , which was devoted to the social activity of LWF member churches. ${ }^{39}$ The study document resulting from it, The Church in the Public Space, ${ }^{40}$ points to the "Engagement for refugee" as one of five key examples of LWF engagement in public space. It was listed as first next to engagement for: overcoming exclusion, gender justice, climate justice, and peaceful interreligious relations. As this activity has been present in the work of the LWF from its very beginnings, this area of service in public space was first mentioned. The document from 2016 refers to two numbers in its context. First of all, it indicates that at the time of its release there were about 60 million refugees in the world,

36 S. Grundmann: Der Lutherische Weltbund. Grundlagen, Herkunft, Aufbau. KölnGraz 1957, pp. 354-363.

37 Proceedings of the Lutheran World Federation Assembly Lund, Sweden June 30July 6, 1947. Philadelphia, Pa 1948, p. 168.

38 Constitution of the Lutheran World Federation (as adopted by the LWF Eighth Assembly, Curitiba, Brazil, 1990, including amendments adopted by the LWF Ninth Assembly, Hong Kong, China 1997 by the LWF Eleventh Assembly, Stuttgart, Germany, 2010, and by the LWF Twelfth Assembly, Windhoek, Namibia, 2017), https:// www.lutheranworld.org/sites/default/files/2018/documents/lwf_constitution_en.pdf, p. 1 [access: 5.08.2019].

${ }^{39}$ M. Junge: "Preface." In: The Church in the Public Space. A Study Document of the Lutheran World Federation. Geneva 2016, pp. 5-6. https://www.lutheranworld.org/sites/ default/files/dtpw-churches_in_public_space.pdf [access: 5.08.2019].

40 The Church in the Public Space. A Study Document of the Lutheran World Federation. Geneva 2016. https://www.lutheranworld.org/sites/default/files/dtpw-churches_in_ public_space.pdf [access: 5.08.2019]. 
and secondly, 2.3 million of them were within the reach of the Department for World Service activities, that is, the LWF's agency responsible for diaconal activities. ${ }^{41}$ Before we take a closer look at this organization, it is worth mentioning that the examples of public involvement indicated above are seen in this document as a consequence of Lutheran theological self-understanding. Discussion of the Lutheran perspective on the role of the church in public space begins with the declaration: "As church we engage in the public space - not in spite of our faith, but inspired by our faith." ${ }^{42}$ The document goes on to indicate the role of the Baptism which: "teaches the church to regard all people as created in the image of God and endowed with equal dignity. Confident that God has reconciled us with Godself, we are liberated to care for others." 43

This implies a commitment to the service of one's neighbour, which was described in reference to the Reformation tradition through the initial theses of Luther's work The Freedom of a Christian:

A Christian is lord of all, completely free of everything.

A Christian is a servant, completely attentive to the needs of all. ${ }^{44}$

This classic text by Luther develops these two theses, pointing out that the gift of salvation offered to man by grace and accepted by faith is the starting point for gratitude for God's grace to take the form of love for his neighbour. The document The Church in the Public Space inscribes this vocation not only in the context of Baptism, but also the Lord's Supper seen as support and strengthening for the Church, a reminder of reconciliation in Christ, which makes Church members ambassadors of reconciliation in the world. Therefore, summing up, the authors of the document state: "The gifts of baptism and Holy Communion constitute and strengthen the church as the community of God's Word. Together they point toward the church's fundamental vocation, namely its holistic mission in proclamation, prophetic diakonia and advocacy work, of which its voice in the public space is an integral part." 45

At this point it is worth pointing to the idea of holistic mission, developed within the LWF since General Assembly in Dar es Salaam in 1977, which helped to overcome a narrow understanding of mission as "aiming at conversion from unbelief to faith," 46 in favour of understanding

${ }^{41}$ The Church in the Public Space..., pp. 27-29.

${ }^{42}$ Ibidem, p. 17.

${ }^{43}$ Ibidem.

${ }^{44}$ Ibidem.

45 The Church in the Public Space..., p. 18.

${ }^{46}$ Mission in Context: Transformation, Reconciliation, Empowerment. An LWF Contribution to the Understanding and Practice of Mission. Geneva 2004, p. 60. https:// 
and practicing mission "in a holistic way as encompassing proclamation, advocacy, and service to the whole person and to all people." 47

The importance of actions for migrants is confirmed by the analysis of the last two so-called LWF Strategies, that is, documents defining the strategic priorities of the organization's activities in the periods between successive General Assemblies. The first of them, implemented in the years 2012-2018 as one of the priorities of LWF activities assumed:

"Effective and empowering diakonia addressing human suffering, injustice, and emergencies." ${ }^{48}$

Among the specific objectives facilitating its implementation was also the following one: “The LWF's global humanitarian and development programs give priority to marginalized and vulnerable poor people whose lives are threatened by conflict, emergencies, and natural disasters, with special regard for refugees and internally displaced persons, people affected by HIV and AIDS and the different needs and capacities of men, women, and children." 49

One of the priorities of LWF's global advocacy was defined as activities for refugees, internally displaced persons and other cases of forced migrations. ${ }^{50}$

The current strategy for 2019-2024, which, like the previous one, appeared under the slogan: "With Passion for the Church and for the World" lists as one of the two main priorities of the LWF: "Promoting human dignity, justice, and peace," ${ }^{51}$ and among the aims leading to its fulfilment names: "As a communion of churches, we will work together to: Respond to people in emergency situations, with a focus on refugees, returnees, internally displaced people, their host communities, and communities at risk." 52

www.lutheranworld.org/sites/default/files/DMD-Mission-in-Context-EN-low.pdf [access: 5.08.2019].

47 Mission in Context..., p. 60.

${ }^{48}$ LWF Strategy 2012-2017 the LWF Communion - With Passion for the Church and for the World. Geneva 2011, p. 24. https://www.lutheranworld.org/sites/default/files/ LWF-Strategy-2012_2017-EN-low_0.pdf [access: 5.08.2019].

${ }^{49}$ LWF Strategy 2012-2017..., p. 24.

${ }^{50}$ Ibidem, p. 25.

51 With Passion for the Church and for the World. LWF Strategy 2019-2024. Geneva 2018, p. 17. https://www.lutheranworld.org/sites/default/files/2018/documents/ strategy-2019-2024/screen/lwf-strategy-2019-2024-report-en-low.pdf [access: 5.08.2019].

52 With Passion for the Church and for the World..., p. 23. 


\section{Global experiences - practical activities of the LWF's Department for World Service for migrants}

The department dealing directly with the issues of working with migrants is the Department for World Service, which has been functioning in the LWF structure since the beginning, that is, since $1947 .{ }^{53}$ Defining in its mission statement for 2019-2024 who they are Department for World Service states:

"LWF World Service is the humanitarian and development arm of the LWF." ${ }_{54}$ Then, the thought is further developed in a following way: "God's liberating grace empowers and calls us to active and constructive engagement with the world. We relate to people in need as our neighbours whom we love and serve and whose dignity we strongly affirm. Our faith affirms the dignity of every human being, and this forms the basis of human rights." 55

In the part devoted to the diagnosis of the present, the strategy notes on the one hand that the situation of people has improved in various respects (escaping poverty, access to education, decreasing infant mortality, etc.). At the same time, it was pointed out that despite these positive trends, we were still observing an increase in the number of displaced persons and refugees. In 2017, according to the United Nations High Commissioner for Refugees (UNHCR), there were 65 million such people, of whom more than half are children. The reasons for this situation include violence, wars, natural disasters, whose negative effects are further aggravated by the effects of climate change. ${ }^{56}$ Centrality of the care for refugees, IDPs, and returnees, as well as host and at-risk communities, was defined as one of the frame priorities for the programmes of the Department for World Service, which should be visible in all areas of its activity. ${ }^{57}$ It is worth noting that the Department for World Service cooperates in the implementation of its goals with many partners: local communities, civil society ( "third sector" organizations), LWF Member Churches, Governments and Other Duty-Bearers, Ecumenical and Interfaith Communities

${ }^{53}$ From Federation to Communion. The History of the Lutheran World Federation. Eds. J.H. Schjøring, P. Kumari, N. Hlejm. Minneapolis, MN 1997, pp. 85-141.

${ }_{54}$ For Hope and a Future. The Lutheran World Federation World Service Global Strategy 2019-2024. Geneva 2018, p. 8. Accessed August 5, 2019, https://www.lutheranworld. org/sites/default/files/2018/documents/lwf_world_service_strategy_2019-2024_english. pdf [access: 5.08.2019].

${ }_{55}$ For Hope and a Future..., p. 8.

56 Ibidem, pp. 12-15.

${ }^{57}$ Ibidem, pp. 25-26. 
(from 2016, Caritas Internationalis is among the partners, while in 2017 the cooperation agreement with Islamic Relief Worldwide was renewed), humanitarian organizations of the member Churches, United Nations Agencies (among others with United Nations High Commissioner for Refugee, World Food Programme, UN Office for Coordination of Humanitarian Affairs), as well as networks of humanitarian organizations. ${ }^{58}$

To give even a brief outline of the results of the LWF's work in helping migrants, we will look at the latest available data for $2018 .{ }^{59}$ In 2018 , work with migrants as part of World Service Departments concerned the main outbreaks of humanitarian crises in the world: Angola, Colombia, Ethiopia, Democratic Republic of Congo (DRC), Kenya, Myanmar, Somalia, South Sudan, and Uganda. Among the reasons why people who received LWF World Service needed help, the most important ones were the armed conflicts, as well as natural disasters (floods, famine, volcanic eruptions). World Service operations in 2018 included a response to the Ebola outbreak in Africa, as well as forced returns to DRC. The World Service also helped people wanting to return to Iraq. Humanitarian aid projects in Iraq, Central Africa Republic, and in Cameroon were continued. The increased activity of Boko Haram in Nigeria meant that the World Service programme had to be expanded to help another wave of 40,000 refugees. The Emergency hub in Central America coordinated assistance for victims of Fuego volcano eruption in Guatemala City. This natural disaster forced more than 1.7 million people to migrate. World service provided basic products (food, hygiene products) and psychosocial support for 11,000 of them. The World Service was also involved in responding to the large scale humanitarian crisis in Bangladesh, caused by the persecution of the Rohingya minority in Myanmar. World Service has taken steps to organize one of the largest refugee camps in the world at Cox's Bazaar in Southern Bangladesh. In addition to continuing to

58 Ibidem, pp. 20-24.

59 Reports on the activities of the Department for World Service for the earlier years are available on the official LWF's website: LWF World Service 2017. Geneva 2018. https://www.lutheranworld.org/sites/default/files/2018/documents/lwf_world_ service_2017.pdf [access: 5.08. 2019]; LWF World Service 2016. Geneva 2017. https:// www.lutheranworld.org/sites/default/files/lwf_worldservice2016.pdf [access: 5.08.2019]; LWF World Service Annual Report 2015. Geneva 2016. https://www.lutheranworld.org/ sites/default/files/dws_annual_report_2015.pdf [access: 5.08.2019]; LWF World Service Annual Report 2014. Geneva 2015. https://www.lutheranworld.org/sites/default/files/ DWS\%20Annual\%20Report\%202014.pdf [access: 5.08. 2019]; Department for World Service Annual Report 2013. Geneva 2015. https://www.lutheranworld.org/sites/default/ files/DWS\%20Annual\%20Report\%202013.pdf [access: 5.08.2019]; World Service Global Report 2012. Geneva 2013. https://www.lutheranworld.org/sites/default/files/World\%20 Service-Global-Report-2012_0.pdf [access: 5.08. 2019]. 
work in the Middle East, for example, in Jordan, World Service also took steps to extend its activities to Syria itself, which was supported by the improvement of international relations between Syria and Jordan. To sum up, in 2018 LWF World Service activities reached over 2.3 million of refugees, internally displaced people, and host communities. ${ }^{60}$

\section{Conclusions}

The foregoing examples of service for migrants show that both at the local level in Poland and globally, Lutherans are active to the advantage of people who experience migration for various reasons. Moreover, an analysis of the global Lutheran reflection at the level of the Lutheran World Federation shows that service to migrants is permanently inscribed in Lutheran identity and is treated as an obvious way of realizing the love of neighbour, to which every Christian is already called in his or her Baptism. This interpretation of Christian vocation in Baptism is clearly developed in recent study documents concerning Church engagement in public space and is assumed in steady commitment reflected in LWF's Constitution. According to this way of thinking, the Church, gifted with God's Word and strengthened by the gift of the Lord's Supper, is called to faithfully realize this baptismal vocation, which is closely connected with gratitude for the gift of salvation and the gift of faith, which is interpreted as a clear commitment to make the world a better place to live for everyone. Holistic mission, understood as a multidimensional service to the whole person in all their needs, has also become, in modern Lutheran understanding, an inseparable indicator of the Church's fidelity to her calling. From these principles derive various actions concerning migrants, focused not only on them, on direct help or financial support, but also on the education of the faithful in the Church, building resources and competences to make this help as effective as possible, or to integrate the problem of migration into spiritual life of the Church, for example, for services for migrants. This engagement takes place not only on the international level, especially through activities of the LWF Department of World Service, but is also a commitment on the level of member Churches and their

${ }^{60}$ Freely you have received, freely give. Annual Report 2018. Geneva 2019, p. 15. https://www.lutheranworld.org/sites/default/files/2019/documents/lwf_annual_ report_2018.pdf [access: 5.08. 2019]; LWF World Service 2018 Annual Report. Geneva 2018, pp. 6-7. https://www.lutheranworld.org/sites/default/files/2019/ documents/190531-ws_2018_annual_report.pdf [access: 5.08.2019]. 
congregations, as was shown on the example of Evangelical Church of Augsburg Confession in Poland. It shows that theological reflection, that provides rationale for such an engagement has its practical dimension in the activities on the grassroots level.

\section{Bibliography}

"About the LWF," https://www.lutheranworld.org/content/about-lwf [access: 5.08.2019].

Brot für die Welt, https://www.brot-fuer-die-welt.de/ [access: 3.04.2019].

Christmas Story (Polski), http://christmasstory.world/polish/christmas-story-polski-117/ [access: 5.08.2019].

ChristmasStory.World, http://christmasstory.world/ [access: 5.08.2019].

Chrześcijańska Akademia Teologiczna w Warszawie, www.chat.edu.pl [access: 5.08.2019].

The Church in the Public Space. A Study Document of the Lutheran World Federation. Geneva 2016, https://www.lutheranworld.org/sites/default/files/dtpwchurches_in_public_space.pdf [access: 5.08.2019].

Constitution of the Lutheran World Federation (as adopted by the LWF Eighth Assembly, Curitiba, Brazil, 1990, including amendments adopted by the LWF Ninth Assembly, Hong Kong, China1997 by the LWF Eleventh Assembly, Stuttgart, Germany, 2010, and by the LWF Twelfth Assembly, Windhoek, Namibia, 2017), https://www.lutheranworld.org/sites/default/files/2018/documents/lwf_constitution_en.pdf

Department for World Service Annual Report 2013. Geneva 2015, https://www. lutheranworld.org/sites/default/files/DWS\%20Annual\%20Report\%202013. pdf [access: 5.08.2019].

Diakonia Koszalin, http://www.diakonia-koszalin.pl/ [access: 5.08.2019].

Diakonie in Mecklenburg-Vorpommern, http://www.diakonie-mv.de/ [access: 4.04.2019].

Dostrzec mitość. Wizyta studyjna pracowników Biura Konsystorza i Diakonii. https://www.luteranie.pl/nowosci/dostrzec_milosc,3164.html [access: 4.03.2019].

Poznać pracę z uchodźcami, https://www.luteranie.pl/nowosci/poznac_prace_z_ uchodzcami,3655.html [access: 4.03. 2019].

"Drugi transport pomocy humanitarnej," http://www.trojca.waw.pl/44-serwisinformacyjny/w-parafii/1132-drugi-transport-pomocy-humanitarnej.html [access: 26.02.2019].

“Dziecięcy Koncert Dobroczynny już w niedzielę 20.01.," http://www.trojca.waw. pl/44-serwis-informacyjny/w-parafii/1466-dzieciecy-koncert-dobroczynnyjuz-w-niedziele-20-01.html [access: 26.02.2019]. 
Dzwony pokoju dla Aleppo. Apel Biskup Kościoła, https://www.luteranie.pl/nowosci/dzwony_pokoju_dla_aleppo,4354.html [access: 4.03.2019].

For Hope and a Future. The Lutheran World Federation World Service Global Strategy 2019-2024. Geneva 2018. https://www.lutheranworld.org/sites/ default/files/2018/documents/lwf_world_service_strategy_2019-2024_ english.pdf [access: 5.08.2019].

Freely you have received, freely give. Annual Report 2018. Geneva 2019. https:// www.lutheranworld.org/sites/default/files/2019/documents/lwf_annual_ report_2018.pdf [access: 5.08.2019].

Fundacja Refugee.pl im. Małgorzaty Jasiczek-Gebert, http://refugee.pl/ [access: 5.08.2019].

Grundmann S.: Der Lutherische Weltbund. Grundlagen, Herkunft, Aufbau. Köln-Graz 1957.

Historia Bożego Narodzenia. Świat wokół nas — projekt filmowy Kościoła Nadrenii. https://www.luteranie.pl/nowosci/historia_bozego_narodzenia,3546.html [access: 4.03.2019].

Instytut Pastoralny Wista Jawornik, 29-31 maja 2015. http://pastoralny.luteranie. $\mathrm{pl} /$ dotychczas/187-2015 [access: 4.03.2019].

Interview with the Polish coordinator of the project, Izabela Gtówka-Sokotowska on April 23, 2019. Unpublished. Note in author's archives.

"Jak działamy," http://www.diakonia.org.pl/o-diakonii/jak-dzialamy/ [access: 5.08.2019].

Junge M.: "Preface." In: The Church in the Public Space. A Study Document of the Lutheran World Federation. Geneva 2016, pp. 5-6, https://www. lutheranworld.org/sites/default/files/dtpw-churches_in_public_space.pdf [access: 5.08.2019].

Konsultacje dotyczace uchodźców. Ekumeniczne spotkanie w Monachium. https:// www.luteranie.pl/nowosci/konsultacje_dotyczace_uchodzcow,3384.html [access: 4.03. 2019].

LWF Strategy 2012-2017 the LWF Communion - With Passion for the Church and for the World. Geneva 2011, https://www.lutheranworld.org/sites/default/ files/LWF-Strategy-2012_2017-EN-low_0.pdf [access: 5.08.2019].

LWF World Service 2016. Geneva 2017, https://www.lutheranworld.org/sites/ default/files/lwf_worldservice2016.pdf [access: 5.08.2019].

LWF World Service 2017. Geneva 2018. https://www.lutheranworld.org/sites/ default/files/2018/documents/lwf_world_service_2017.pdf [access: 5.08 . 2019].

LWF World Service 2018 Annual Report. Geneva 2018, https://www.lutheranworld. org/sites/default/files/2019/documents/190531-ws_2018_annual_report.pdf [access: 5.08.2019].

LWF World Service Annual Report 2014. Geneva 2015, https://www. lutheranworld.org/sites/default/files/DWS\%20Annual\%20Report\%202014. pdf [access: 5.08.2019].

LWF World Service Annual Report 2015. Geneva 2016, https://www.lutheranworld. org/sites/default/files/dws_annual_report_2015.pdf [access: 5.08.2019]. 
Mączka-Pacholak M., Morawska Z., Radziejowska M.: Pomoc dla uchodźców. Vademecum dla Parafii Ewangelicko-Augsburskiej. 19 listopada 2015. unpublished materials in the author's archive.

Message from the Churches in Poland concerning Refugees, https://ekumenia.pl/ content/uploads/2016/06/przeslanie-Kosciolow-w-sprawie-uchodzcow-EN. pdf [access: 4.04.2019].

“Migrating exhibitions," http://refugee.pl/en/information/migrating-exhibitions/ [access: 5.08.2019].

Mission in Context: Transformation, Reconciliation, Empowerment. An LWF Contribution to the Understanding and Practice of Mission. Geneva 2004, https://www.lutheranworld.org/sites/default/files/DMD-Mission-in-ContextEN-low.pdf [access: 5.08.2019].

Modlitwa i wzajemna miłość. Biskup Kościoła podczas Tygodnia Modlitw o Jedność Chrześcijan, https://www.luteranie.pl/nowosci/modlitwa_i_wzajemna_ milosc,3622.html [access: 4.03.2019].

Na pomoc uchodźcom. Apel Diakonii Polskiej, https://www.luteranie.pl/nowosci/ na_pomoc_uchodzcom,3185.html [access: 4.03.2019].

Nabożeństwo ekumeniczne oraz wystawa fotografii, http://www.trojca.waw.pl/44serwis-informacyjny/w-parafii/1461-nabozenstwo-ekumeniczne-oraz-wystawa-fotografii.html [access: 26.02.2019].

“Nie możemy stać obojętni. Zebrano ofiarę na pomoc uchodźcom,” https:// www.luteranie.pl/nowosci/nie_mozemy_stac_obojetni,3419.html [access: 4.03.2019].

“Otwarcie wystawy w ramach projektu Uchodźca. Brat. Człowiek," https://www. trojca.waw.pl/44-serwis-informacyjny/w-parafii/1463-otwarcie-wystawy-wramach-projektu-uchodzca-brat-czlowiek.html [access: 26.02.2019].

Otwórzmy serca dla uchodźców. List pasterski Biskupa Kościoła, https://www. luteranie.pl/nowosci/otworzmy_serca_dla_uchodzcow,3175.html [access: 4.04.2019].

Parafia Ewangelicko-Augsburska Jezusa Dobrego Pasterza w Koszalinie, http:// koszalin.luteranie.pl/ [access: 5.08.2019].

Parafia Ewangelicko-Augsburska św. Trójcy w Warszawie, http://www.trojca. waw.pl/ [access: 5.08.2019].

Photo Exhibition at The Holy Trinity Lutheran Church in Warsaw, http:// refugee.pl/en/information/art-exhibition/ [access: 5.08.2019].

"Pomoc dla uchodźców przekazana Zakończono akcję w Parafii św. Trójcy w Warszawie," https://www.luteranie.pl/nowosci/pomoc_dla_ uchodzcow_przekazana,3510.html [access: 5 .08.2019].

"Pomoc dla uchodźców," http://www.trojca.waw.pl/44-serwis-informacyjny/wparafii/1087-pomoc-dla-uchodzcow.html [access: 26.02.2019].

"Pomoc dla uchodźców przekazana," http://www.trojca.waw.pl/44-serwisinformacyjny/w-parafii/1104-pomoc-dla-uchodzcow-przekazana.html [access: 26.02.2019].

Proceedings of the Lutheran World Federation Assembly Lund, Sweden June 30July 6, 1947. Philadelphia, Pa 1948. 
Program TE Dzięgielów 2018, https:/cme.org.pl/content/uploads/2018/04/ Program_TED_2018_.pdf [access: 4.03.2019].

Projekt „Ekumeniczny punkt konsultacyjny ds. migracji - Gościnny Kościót”, https://ekumenia.pl/goscinny-kosciol/ [access: 4.03.2019].

Przekraczając granice - zrozumieć uchodźców. Projekt warsztatów dotyczących sytuacji uchodźców w Polsce, https://www.luteranie.pl/nowosci/ przekraczajac_granice_zrozumiec_uchodzcow,5446.html [access: 4.03.2019].

Razem - Infopunkt dla migrantów / Разом- пункт інформації для мігрантів. https://www.facebook.com/razeminfopunkt/ [access: 3.04.2019].

Razem - Infopunkt dla migrantów, https://www.razeminfopunkt.pl/ [access: 3.04.2019].

Relacja z konferencji „Uchodźca. Brat. Człowiek” - Chrześcijańska Akademia Teologiczna w Warszawie, http://chat.edu.pl/aktualnosci/relacja-zkonferencji-uchodzca-brat-czlowiek/?fbclid=IwAR0zWc5RvmoDKdp-OpakA pZI8UZHHjkCUD9gyHDkNhuXICZ7hIG5M8XRnf0 [access: 26.02.2019].

"Sami byliście przychodniami. Konsultacje międzykościelne i Synod EKiR," https://www.luteranie.pl/nowosci/sami_byliscie_przychodniami,3592.html [access: 4.03. 2019].

From Federation to Communion. The History of the Lutheran World Federation. Eds. J.H. Schjøring, P. Kumari, N. Hlejm. Minneapolis 1997.

Sesja Instytutu Pastoralnego 15-20 lutego 2016 r., Wrocław, http://pastoralny. luteranie.pl/tematyka-sesji/194-2016-wroclaw [access: 4.03.2019].

"Siła modlitwy w Krakowie," https://www.luteranie.pl/nowosci/sila_ modlitwy_w_krakowie,3233.html [access: 4.03.2019].

Światowy Dzień Uchodźcy. Oświadczenie Konsystorza i Rady Synodalnej, https:// www.luteranie.pl/nowosci/swiatowy_dzien_uchodzcy,5562.html [access: 4.03.2019].

Światowy Dzień Uchodźcy. Oświadczenie Konsystorza i Rady Synodalnej, https:// www.luteranie.pl/nowosci/swiatowy_dzien_uchodzcy,5562.html [access: 4.03.2019].

Uchodźca. Brat. Człowiek. Konferencja $i$ wystawa, http://chat.edu.pl/app/ uploads/2019/02/uchodzca-brat-czlowiek-3.pdf [access: 26.02.2019].

W obozie dla uchodźców w Jordanii, https://www.luteranie.pl/nowosci/w_obozie_ dla_uchodzcow_w_jordanii,4316.html [access: 4.03.2019].

With Passion for the Church and for the World. LWF Strategy 2019-2024. Geneva 2018, https:/www.lutheranworld.org/sites/default/files/2018/documents/ strategy-2019-2024/screen/lwf-strategy-2019-2024-report-en-low.pdf [access: 5.08.2019].

Who we are. https://ekumenia.pl/kim-jestesmy/?lang=en [access: 5 VIII 2019].

World Service Global Report 2012. Geneva 2013, https://www.lutheranworld. org/sites/default/files/World\%20Service-Global-Report-2012_0.pdf [access: 5.08.2019].

Wsparcie od polskich luteran. Przekazano środki finansowe dla uchodźców, https:// www.luteranie.pl/nowosci/wsparcie_od_polskich_luteran,3957.html [access: 4.03. 2019]. 
Wystawa fotografii o życiu uchodźców 7-27 stycznia, http://www.trojca. waw.pl/44-serwis-informacyjny/w-parafii/1465-wystawa-fotografii-o-zyciuuchodzcow-7-27-stycznia.html [access: 26.02.2019].

JERZY SOJKA

Servizio luterano ai migranti. Esperienze polacche e globali

Abstract

L'articolo presenta l'impegno luterano nei confronti dei migranti sull'esempio delle attività intraprese dalla Chiesa evangelico-augusta in Polonia, nonché dalla Federazione luterana mondiale, ovvero la più grande organizzazione mondiale di Chiese luterane nel mondo. Relativamente alla Chiesa evangelica di Augusta, nel presente testo si passa in rassegna le iniziative intraprese dal 2015 per servire i migranti a livello parrocchiale e ecclesiale, nonché in collaborazione con i partner ecumenici (anche all'interno del Consiglio ecumenico polacco e in cooperazione con la Chiesa cattolica). Nel caso della Federazione Luterana Mondiale, in una prima fase del discorso, è stata presentata la giustificazione teologica del coinvolgimento della Federazione nel lavoro a favore dei migranti, e nella successiva, si è delineato il lavoro del Dipartimento dei servizi mondiali (agenda umanitaria della Federazione) nel 2018.

Parole chiave: Federazione Luterana Mondiale, migranti, la missione della Chiesa, la Chiesa evangelico-augusta in Polonia

JERZY SOJKA

\section{Service luthérien aux migrants. Expériences en Pologne et au niveau mondial}

Résumé

L'article présente l'engagement luthérien en faveur des migrants sur l'exemple des activités entreprises par l'Église évangélique d'Augsbourg en Pologne, ainsi que la Fédération luthérienne mondiale, c'est-à-dire la plus grande organisation mondiale d'Églises luthériennes dans le monde. Dans le cas de l'Église évangélique d'Augsbourg, le texte passe en revue les initiatives entreprises depuis 2015 pour aider les migrants au niveau paroissial et ecclésial, ainsi qu'en coopération avec des partenaires œcuméniques (y compris au sein du Conseil œcuménique polonais et de la coopération avec l'Église catholique). En ce qui concerne la Fédération luthérienne mondiale, dans un premier temps, le ette a présenté la justification théologique de l'engagement de la Fédération dans le travail en faveur des migrants, et dans un second temps, on a décrit le travail du Département des services mondiaux (agenda humanitaire de la Fédération) en 2018.

Mots clés: Fédération luthérienne mondiale, migrants, mission de l’Église, Église évangélique-Augsbourg en Pologne 